\title{
State regulation of the development of small business forms
}

\author{
Liliya Mikhailova*, Fayaz Avkhadiev, Nail Asadullin, and Ilgizar Gainutdinov \\ Kazan State Agrarian University, Kazan 420015, Russia
}

\begin{abstract}
The purpose of this work is to study the fundamentals of doing business in the form of small businesses in the Russian Federation, the general goals of state support for small businesses, identifying the main problems of agricultural producers in the countryside, and developing recommendations for solving existing problems in the framework of developing small and medium-sized businesses in country. Agricultural entrepreneurship in Russia began to develop actively in the 1990s; at present, due to the not very favorable economic situation in the country and in the world in general, entrepreneurship in agriculture is going through difficult times. The main reasons for this state of affairs can be considered the lack of funds from producers for the material and technical supply of their production, the lack of domestic and foreign investors in this risky industry. Also, with a change in the dollar exchange rate, it is difficult for entrepreneurs to purchase expensive foreign equipment and many other tools that are necessary when doing business, all these factors substantiate the relevance of this study: the need to increase the level of state assistance to small and medium-sized enterprises. The practical significance of the study consists in the development of certain measures for the organizational and economic development of small agribusiness and its support from the state.
\end{abstract}

\section{Introduction}

The fundamentals of doing business in the form of small business forms are to a large extent characteristic of the agricultural sector of the economy. In the Russian Federation, the structure is involved in the formation of a reserve of food funds, and is also an incentive for the further development of the market for agricultural products, ensures the implementation of targeted programs, which mediates the development of interagency entrepreneurship in the agricultural sector. The use of such programs should be taken into account as the overall impact of state support for small family farms and large agricultural organizations. In the context of the ineffective implementation of instruments of state support for entrepreneurship in the agricultural sector, the activities of the legislative and executive authorities in this area are not systemic and do not create an optimal market environment for entrepreneurship [1].

The need to increase the level of state assistance to entrepreneurship in the agricultural sector of Russia is explained by a reduction in the real income of agricultural producers, a decrease in the volume of agricultural production, and the deterioration of some economic indicators of production and commercial activities of farms in the field of crop production and livestock.

It is no secret that small business in Russia is developing at slower paces compared to other developed countries. Foreign countries have comprehended the importance and necessity of supporting entrepreneurship for the stable development of the entire economy for a relatively long time. If you study the statistics, you can identify that the business sector in many developed countries is $70-90 \%$ of the total number of firms.

As a successful example of these states shows, it is necessary to focus more expressed attention towards the effective development of small business in order to increase the economic well-being of the whole country. We cannot say that everything is bad in our country, as some ways to support small and medium-sized enterprises have already been adopted. Be that as it may, the state is trying to resolve issues, problems and difficulties regarding small and medium-sized enterprises.

Currently, more serious steps are already visible in the country and as a result, progress in the field of political support for entrepreneurial activity.

\section{Materials and Methods}

The theoretical and methodological base of the study is founded on the use of the possibility of interaction and complementarity of fundamental principles and concepts of economic theory. The theoretical and methodological basis was also made by the works of foreign and domestic economists and agrarians on the topic under study, regulatory acts of the Russian Federation on the regulation of agricultural and food policy, as well as the national project "Small and medium enterprises and the support of individual entrepreneurial initiative", materials from international and Russian scientific practical conferences on agricultural development.

* Corresponding author: lilmikhajlova@yandex.ru 
The general methodological basis of the study is system analysis. The vast material and the diversity of their content necessitated the use of various approaches, methods and techniques for the scientific study of socioeconomic processes, such as constructive, deterministic, retrospective, dynamic, and statistical, within the framework of system analysis.

In the course of the study, methods were used to reveal the trends in the development of agri-food policy and the features of their manifestation: monographic, abstract-logical, computational-constructive, economicstatistical, analogies.

As the informational and factual basis of the study, we used official data of the Federal State Statistics Service of the Russian Federation, the Ministry of Agriculture of the Russian Federation, the Ministry of Agriculture and Food of the Republic of Tatarstan, planning and reporting documents of agricultural organizations, materials contained in monographs, dissertations, reports of research institutes, in publications, materials of scientific conferences, expert evaluations, data obtained during the author's analysis and calculations.

\section{Results}

The general objectives of state support for small business in Russia are:

- creating favorable conditions for the functioning of the business;

- control over the implementation of legislation;

- distribution of responsibility of state bodies in the system of supporting small business;

- legislative consolidation of investment in small businesses from the budget;

- Information support.

By themselves, small forms of managing cannot provide the entire population of the state. However, in aggregate they are capable of producing exactly the same output as all large state agricultural enterprises and provide a sufficient market share (Table 1). This circumstance once again emphasizes the large role in the country's economy of small and medium enterprises in the agricultural sector.

An analysis of these indicators indicates a sufficient presence of the sector of small and medium-sized enterprises in providing food to the population. In this regard, in Russia there is some support for small agribusiness entities.

The forms of state assistance to small entrepreneurs include:

- the provision of refundable and gratuitous financial support;

- financing of federal programs of support and development of small business;

- providing tax benefits to small organizations that are engaged in priority activities;

- giving small firms the opportunity to receive government orders for the production and supply of certain types of products and goods (works, services) for state needs by organizing a tender;
- and other forms of assistance.

Table 1. Agricultural products by categories of farms in the Russian Federation, billion rubles

\begin{tabular}{|l|c|c|c|c|}
\hline \multirow{2}{*}{ Enterprises } & \multicolumn{4}{|c|}{ Years } \\
\cline { 2 - 5 } & 2016 & 2017 & 2018 & 2019 \\
\hline $\begin{array}{l}\text { Agricultural } \\
\text { organizations } \\
\text { all products }\end{array}$ & 2818.4 & 2818.5 & 3022.1 & 3438.5 \\
\hline $\begin{array}{l}\text { including livestock } \\
\text { products }\end{array}$ & 1390.0 & 1482.2 & 1583.3 & 1708.5 \\
\hline $\begin{array}{l}\text { crop production } \\
\text { Households } \\
\text { all products }\end{array}$ & 1428.4 & 1336.3 & 1438.8 & 1730.0 \\
\hline $\begin{array}{l}\text { including livestock } \\
\text { products }\end{array}$ & 1659.2 & 1655.4 & 1656.7 & 1665.7 \\
\hline crop production & 768.3 & 891.2 & 869.6 & 885.7 \\
\hline $\begin{array}{l}\text { Peasant (farmer) } \\
\text { households } \\
\text { all products }\end{array}$ & 634.7 & 635.6 & 670.0 & 803.7 \\
\hline $\begin{array}{l}\text { including livestock } \\
\text { products }\end{array}$ & 121.7 & 136.4 & 139.8 & 153.7 \\
\hline crop production & 513.0 & 499.2 & 530.2 & 650.0 \\
\hline $\begin{array}{l}\text { All enterprises } \\
\text { all products }\end{array}$ & 5112.3 & 5109.5 & 5348.8 & 5907.9 \\
\hline $\begin{array}{l}\text { including livestock } \\
\text { products }\end{array}$ & 2402.0 & 2509.8 & 2592.7 & 2747.9 \\
\hline crop production & 2710.3 & 2599.7 & 2756.1 & 3160.0 \\
\hline
\end{tabular}

In modern conditions, state support for entrepreneurship in the agricultural sector of the Russian Federation is aimed at eliminating the control mechanism inherent in the administrative planning system, implementing incentive measures for lending to various entities, reforming the taxation of agricultural organizations and peasant (farmer) households. But at the same time, the application of traditional economic methods, which provide a certain level of budget, financial and production constancy, is not currently accompanied by the development of agribusiness, which indicates the inefficiency of some tools.

The development of small and medium-sized businesses in Russia is still far behind countries such as Germany, Korea, Italy. The share of small and mediumsized businesses in the economy of our country is only $23 \%$, while in many foreign countries this indicator is 2 , or even 3 times higher.

The study of the issue in the field of small business in a regional aspect, using the example of the Republic of Tatarstan, allows making certain conclusions and forecasts.

The Republic of Tatarstan is one of the most economically advanced regions of Russia. The Republic creates the necessary conditions for the development of small business. Based on the above measures, in the framework of the National project "Small and mediumsized enterprises and support of individual entrepreneurial initiatives", five projects are being implemented in the republic:

1. Improving the business environment.

2. Expanding access of small and medium-sized businesses to financial resources, including preferential financing. 
3. Acceleration of small and medium-sized enterprises.

4. Creation of a system of support for farmers and the development of rural cooperation.

5. Promotion of entrepreneurship.

The policy in the sphere of small and medium agribusiness pursued in the Republic of Tatarstan allows holding leading positions among the subjects of Russia in the number of business support infrastructure facilities, including their special economic zones, technology parks, republican business incubators, industrial parks, regional engineering centers, and centers for youth innovative creativity.

In a situation of high volatility in the foreign exchange market and a decrease in investment inflows from abroad, small and medium-sized businesses are a driver for the development of the republican economy. Owing to their greater mobility, entrepreneurs have a higher chance of rapid development. In the context of a decrease in the flow of goods from abroad and increased government support for small and medium-sized businesses, it is important not to miss the potential of launching small and medium-sized enterprises aimed at developing emerging market niches and creating new products.

If the existing market conditions are not used, then already in the short term there will be a return to the import of goods and services in the same volume. It is important to seize the opportunity in the next $2-3$ years.

The economic system of our state consists of a combination of various fields of activity, including small and medium-sized enterprises. This business solves both economic and social problems. An example of this is the fact that new enterprises offer new jobs to the population. In addition, any organization, as you know, is a taxpayer, and, as a result, we can say that such a business promotes pure competition, that is, favorably affects the economic atmosphere as a whole [2, 3].

As a result, it is not difficult to understand that entrepreneurship is necessary for every state, however, in each field of activity there are certain barriers and development problems. There is an opinion that the share of ruined, bankrupt entrepreneurs in Russia is greater than the share of newly created enterprises that have re-entered the entrepreneurs' market.

To date, small business forms in the Russian Federation include:

- 17.3 million personal subsidiary plots of the population;

- 253 thousand peasant (farm) households;

- about 32 thousand individual entrepreneurs.

Within Tatarstan, small forms of management in the agricultural sector are represented by over 450 thousand private, more than 4 thousand farms and 273 agricultural consumer cooperatives.

In general, 2019 was a favorable year for farmers in the republic in order to develop entrepreneurship: it is characterized by an increase in all types of livestock and poultry, an increase in cash revenue, as well as the total number of employees. So, for example, the number of cattle has reached 101.7 thousand animals, which is a third (or 32 thousand animals) more than in 2015.
We managed to achieve positive results of work thanks to the volume of state support of small forms: this is over 2 billion rubles annually, and 2.5 billion rubles by 2019. Main support was provided through grants to farmers and cooperatives (1.3 billion rubles in 2019), subsidies to private farms (over 500 million rubles annually).

In addition to subsidies to preserve the dairy herd, a program for the construction of mini-farms is being implemented. For example, for the period from 2015 to 2019, 1865 mini-farms were built with state support from the republican budget for 360 million rubles, while the increase in the number of livestock amounted to 5 thousand cows.

Active work in the republic is carried out on the sale of products through electronic forms of trade. There are already 40 sites operating here, where volumes of various agricultural products are formed and, at the request of customers, they are delivered to their homes by electronic application. So, only through the Plantation Station platform 18 thousand orders are received annually.

For 2020, all types of support for personal subsidiary farms for the construction of mini-farms, the purchase of poultry, the maintenance of mares older than 3 years, the purchase of heifers and first-calf heifers, for veterinary services, and for the maintenance of dairy herds are preserved.

Conditions and volumes of grant support for the development programs of family farms (350 million rubles), novice farmers (250 million rubles), cooperatives (300 million rubles) are preserved. Also, the federal project "Creating a Support System for Farmers and Develop Cooperation" will be continued federal legislation increased the amount of grants for the Agrostartap project in the dairy and meat sector of cattle to 5 million rubles for a farmer's business project and up to 6 million rubles in the case of sending part of the grant to the development of the cooperative in which they are member in.

Another important point for the region is the fact that among the key areas is the involvement of rural residents in entrepreneurial activity, increasing their employment and income [4-6].

Of course, there are also many problems in the sphere of small and medium-sized enterprises, the main obstacles for doing business are still high bank interest for small enterprises, the lack of insurance of entrepreneurial risks, etc., which cannot be solved without government intervention.

In addition, there are difficulties in obtaining state support, since this procedure takes several months, since it is necessary to pass the control of a large number of committees and departments, which are not so easy and quick to implement.

The results of activities of small businesses are also affected by the impact of low purchasing power of the population and high competition.

Our domestic enterprises are not always able to compete with foreign enterprises. There is such a problem as a lack of investment in the processing sector of small business, for example: updating of production 
assets is required. All this requires huge investments, which an organization does not always possess [7-9].

There is another problem with regards to especially agrarian entrepreneurship as a lack of information, especially for rural residents.

Many directions were taken to solve these problems, but, unfortunately, not all measures taken brought the desired result. It should be noted that:

- firstly, entrepreneurship simply needs support, attention and control from state authorities. The main direction, according to experts, is the financial support of small business from the state. The principal point is the creation of a favorable business climate;

- secondly, it is important to adopt laws and regulations that will help regulate entrepreneurial activity;

- thirdly, it is necessary to create and provide consulting assistance for the rural population in the form of providing training courses that would help to understand the correct direction of business development, as well as its feasibility.

For a fairly developed small business sector, it is necessary to:

- focus state aid in order to stimulate innovation in business;

- create conditions for the formation of an integrated system for supporting agribusiness (leasing, franchising);

- create conditions to support small and medium enterprises from the federal to the municipal level;

- create conditions and encourage cooperation between large, medium and small businesses for closer legal and economic interaction, start working on the constitutional status of medium-sized businesses;

- to develop a systematic approach to guaranteeing and insuring the investment risks of small businesses, especially with regard to debt investments;

- annually provide to the budgets of the regions of Russia and municipalities the distribution of preferential state and municipal investment loans in order to support small businesses [10, 11].

Summing up, we can say that all problems are solved, albeit not immediately, but gradually. Our state realizes the support of small and medium enterprises, which means that more and more effective enterprises will open annually. The government does not forget about the problems in this field of activity, quite often issues related to small business are raised at meetings, that is, the state has serious intentions regarding small business.

\section{Conclusions}

Based on the results obtained, the following conclusions can be drawn:

1. The fundamentals of doing business in the form of small business forms are to a large extent characteristic of the agricultural sector of the economy. As the experience of developed countries shows, only with strict accounting for the specifics, primarily related to natural characteristics, positive results in the entrepreneurial activity of the industry can be achieved.

2. State support of entrepreneurship in the agricultural sector of the Russian Federation is aimed at the implementation of incentive measures for lending to various entities, reforming taxation for small and medium enterprises represented by agricultural organizations and peasant (farmer) enterprises. But at the same time, the application of traditional economic methods, which provide a certain level of budget, financial and production constancy, is not currently accompanied by the development of agribusiness, which indicates the inefficiency of some tools.

3. The increasing role of entrepreneurship in the economy of Russia and other developed countries is a necessary regularity caused by the very course of history. Understanding the above factors leads to the fact that the country has thoroughly taken up the development of programs and strategies for state aid policies that are aimed at improving small and mediumsized enterprises.

\section{References}

1. E.F. Amirova, I.N. Safiullin, L.G. Ibragimov, N.V. Karpova, Bull. of Kazan State Agrar. Univer., 3(54), 133-137 (2019)

2. F.N. Mukhametgaliev, L.F. Sitdikova, M.M. Khismatullin, N.M. Asadullin, L.V. Mikhailova, BIO Web of Conf., 17 (2020) Retrieved from: https://doi.org/10.1051/bioconf/20201700059

3. F.N. Mukhametgaliev, L.F. Sitdikova, F.F. Mukhametgalieva et al., Stud. on Russ. Econ. Developm., 2, 162-165 (2019)

4. D.F. Khafizov, M.M. Khismatullin, Bull. of Kazan State Agrar. Univer., 3(50), 157-161 (2018)

5. L.V. Mikhailova, D.R. Nigmatzyanova, Vector of Econ., 10(28), 108-111 (2018)

6. F.N. Avkhadiev, Niva of Tatarstan, 6, 18-21 (2002)

7. I.G. Gainutdinov, A.R. Yusupov, Vector of Econ., 12(42), 57-63 (2019)

8. L.V. Mikhailova, A.I. Rakhcheva, Vector of Econ., 11(29), 125-130 (2018)

9. D.F. Khafizov, M.M. Akhsanov, M.M. Khismatullin, Sci. Rev.: Theory and Pract., 8, 45-52 (2018)

10. L.M. Petrova, AIC: Econ., Manag., 4, 93-98 (2020)

11. I.A. Mironov, Young Scientist, 47(233), 253-255 (2018) 